\title{
Effects of Ozone on Photosynthetic Components and Radical Scavenging System in Leaves of Rice (Oryza sativa L.)
}

\author{
Hidetoshi INADA*, Masahiro YAMAGUCHI*, Ryohei SATOH*, Daiki HOSHINO*, \\ Aki NAGASAWA*, Yoh NEGISHI*, Isamu NOUCHI**, \\ Kazuhiko KOBAYASHI**, and Takeshi IZUTA* \\ *Institute of Symbiotic Science and Technology, Tokyo University of Agriculture and Technology, \\ Tokyo, 183-8509 Japan \\ **Graduate School of Agricultural and Life Sciences, The University of Tokyo, Tokyo, 113-8657 Japan
}

\begin{abstract}
The chronic effects of ambient levels of $\mathrm{O}_{3}$ on photosynthetic components and radical scavenging system of leaves at different positions on the main stem of Japanese rice (Oryza sativa L.) were investigated. Two cultivars of Japanese rice (Koshihikari and Kinuhikari) were planted in plastic boxes filled with flooded Andisol in 9 chambers on 15 May, and exposed daily to charcoal-filtered air or $\mathrm{O}_{3}$ at 60 or $100 \mathrm{nl} \mathrm{l}^{-1}$ (ppb) (10:00-17:00) from 30 May to 20 September 2007.

The activity and concentration of ribulose 1,5-bisphosphate carboxylase/oxygenase (Rubisco) in the leaves of both cultivars were not significantly affected by exposure to $\mathrm{O}_{3}$. However, the concentrations of chlorophyll in the lower leaves on the main stem of both cultivars were significantly reduced by the exposure to $100 \mathrm{ppb} \mathrm{O}_{3}$, while the exposure to $\mathrm{O}_{3}$ significantly increased the activities of ascorbate peroxidase (APX), monodehydroascorbate reductase (MDAR) and glutathione reductase (GR); regardless of the leaf position in the two cultivars. Although no significant combined effect of $\mathrm{O}_{3}$ and cultivar on the concentration of chlorophyll, the activity and concentration of Rubisco, or the concentration of antioxidants and activity of radical scavenging enzymes was observed, there was a highly positive correlation between the AOT40 (accumulated exposure over a threshold of $40 \mathrm{ppb}$ ) of $\mathrm{O}_{3}$ and the relative activity of APX, MDAR or GR in leaves exposed to $\mathrm{O}_{3}$ to that in leaves exposed to charcoal-filtered air of both cultivars. These results suggest that APX, MDAR and GR played important roles in the antioxidative response of Japanese rice to $\mathrm{O}_{3}$. However, the detoxification capacity of reactive oxygen species by APX, MDAR and GR was insufficient to prevent the adverse effects of ambient levels of $\mathrm{O}_{3}$ on the concentration of chlorophyll in the two cultivars of Japanese rice.
\end{abstract}

Key words: Antioxidant, Oryza sativa, Ozone, Radical scavenging enzymes, Rubisco.

\section{Introduction}

Tropospheric ozone $\left(\mathrm{O}_{3}\right)$ is a major component of photochemical oxidants and generated by photochemical reaction in the atmosphere under sunlight (Chameides et al. 1994). Recent modeling work by the United Kingdom Meteorological Office, using the IPCC-A2 emission scenario, indicates possible expansion of the area subjected to elevated summertime $\mathrm{O}_{3}$ in coming decades with hotspots in North and South America, Eu-

Received; March 21, 2008.

Accepted; August 5, 2008. rope and Asia (Collins et al. 2000). Recently, relatively high concentrations of $\mathrm{O}_{3}$ have been observed in East Asia (Zheng and Shimizu 2003). In Japan, according to the ambient air quality data of the Atmospheric Environmental Regional Observation System in the National Institute for Environmental Studies, relatively high concentrations of $\mathrm{O}_{3}$ above $100 \mathrm{nl} \mathrm{l}^{-1}$ (ppb) have frequently been detected in suburban areas and the average concentration of $\mathrm{O}_{3}$ has been rising year by year (Ohara et al. 2007). Relatively high concentrations of $\mathrm{O}_{3}$ induce visible foliar injuries, inhibition of net photosynthesis and a reduction in growth and yield 
of many crops (Fuhrer et al. 1997; Heck et al. 1982; Nouchi et al. 1991). Furthermore, it has been reported that ambient levels of $\mathrm{O}_{3}$ in suburban areas of Japan might induce a reduction in the growth and yield of several crops (Kobayashi 1988).

Ozone enters the leaves of crops primarily through the stomata. Interacting with water in the leaf extracellular spaces, $\mathrm{O}_{3}$ degrades into reactive oxygen species (ROS) such as superoxide anion $\left(\mathrm{O}_{2}^{-}\right)$, hydrogen peroxide $\left(\mathrm{H}_{2} \mathrm{O}_{2}\right)$, hydroxyl radical $\left(\mathrm{OH}^{-}\right)$and other free radicals (Hoigné and Bader 1976). Ozone-induced ROS may damage biomolecules in leaf cells such as membrane lipids, proteins and nucleic acids (Hippeli and Elstner 1996; Fuhrer and Booker 2003). Furthermore, several researchers reported that $\mathrm{O}_{3}$-induced ROS in the leaves of crops caused a reduction in the amount of ribulose 1, 5-bisphosphate carboxylase/oxygenase (Rubisco) and the inhibition of photosynthetic activity (Dann and Pell 1989; Farage et al. 1991).

The difference in the sensitivity to $\mathrm{O}_{3}$ among the cultivars of a crop might be related to the detoxification capacity for $\mathrm{O}_{3}$-induced oxidative damage in the leaves (Cheng et al. 2007; Izuta et al. 1999; Fuhrer and Booker 2003; Nouchi 1993). For example, Cheng et al. (2007) reported that the detoxification capacity of $\mathrm{O}_{3}$-tolerant cultivar exceeded that of the $\mathrm{O}_{3}$-sensitive cultivar in soybean. In many crops, $\mathrm{O}_{3}$-induced $\mathrm{ROS}$ can stimulate the synthesis of antioxidative metabolites and enhance the activity of radical scavenging enzymes. For example, $\mathrm{O}_{2}^{-}$is eliminated by superoxide dismutase (SOD) in a reaction that yields hydrogen peroxide $\left(\mathrm{H}_{2} \mathrm{O}_{2}\right)$. Hydrogen peroxide $\left(\mathrm{H}_{2} \mathrm{O}_{2}\right)$ is then scavenged by ascorbate peroxidase (APX) and catalase (CAT), whereupon ascorbate is regenerated by the reduction of monodehydroascorbate radical by monodehydroascorbate reductase (MDAR) and NADPH. The glutathione pathway is catalyzed by dehydroascorbate reductase (DHAR) and glutathione reductase (GR). It has been reported that the levels of certain antioxidants and the activity of several radical scavenging enzymes in rice were increased by exposure to $\mathrm{O}_{3}$ (Nouchi 1993; Yoshida et al. 1994a; Yoshida et al. 1994b). However, the detoxification capacity depends on the concentration of $\mathrm{O}_{3}$, exposure period, age of plant tissues and genotype (Cheng et al. 2007; Bender et al. 1994).

Rice (Oryza sativa L.) is a primary agricultural crop in Japan. The short-term effect of $\mathrm{O}_{3}$ on the photosynthetic components and radical scavenging systems of Japanese rice leaves were reported (Nouchi et al. 1991; Nouchi 1993; Yoshida et al. 1994a; Yoshida et al. 1994b). However, no information concerning the long-term (chronic) effects of ambient levels of $\mathrm{O}_{3}$ on photosynthetic components and radical scavenging systems of Japanese rice leaves is available. In the present study, we investigated the chronic effects of ambient levels of $\mathrm{O}_{3}$ on the concentration of chlorophyll, activity and concentration of Rubisco, concentration of antioxidants and the activity of radical scavenging enzymes in the leaves at different positions on the main stem of two cultivars of Japanese rice.

\section{Materials and Methods}

\subsection{Plant materials and gas treatment}

In the present study, two cultivars of Japanese rice, Koshihikari and Kinuhikari, were used as plant materials. These are early to medium maturing cultivars (National Institute of Crop Science Rice Breeding Research Team, 2007). Rice seeds were obtained from the Field Production Science Center in the University of Tokyo. The 1500 seeds pre-germinated in water for 3 days were sown into seedling boxes $(60 \mathrm{~cm} \times$ $33 \mathrm{~cm}$ and a depth of $30 \mathrm{~mm}$ ) filled with cultivation molding on 20 April, 2007. After incubation in a greenhouse, the seedlings were planted in plastic boxes (42.5 1) filled with flooded andisol (32.4 1) on 15 May, and grown until 20 September, 2007 in 9 chambers located at the Field Museum Tamakyuryo of Tokyo University of Agriculture and Technology (Hachioji, Tokyo). Fertilizer (N-P-K=14:14:14) was applied before planting at $25 \mathrm{~g}$ per box. Each chamber was $2.2 \mathrm{~m}$ width $\times 2.6 \mathrm{~m}$ depth $\times 2.0 \mathrm{~m}$ height. For each cultivar, 6 plants were planted in a plastic box, and 12 boxes were assigned to each chamber for a total of 648 plants.

The two cultivars were exposed daily to charcoalfiltered air or $\mathrm{O}_{3}$ at $60 \mathrm{nl} \mathrm{l}^{-1}$ (ppb) or $100 \mathrm{ppb}$ (10:00-17:00) with 3 chamber replications from 30 May to 20 September 2007 . The whole-plant dry mass and leaf area per plant at the beginning of the exposure to $\mathrm{O}_{3}$ (29 May, 2007) were $141.1 \pm 5.9 \mathrm{mg}$ and $21.2 \pm 1.7 \mathrm{~cm}^{2}$ for Koshihikari, and $135.9 \pm 1.5 \mathrm{mg}$ and $15.4 \pm 0.7 \mathrm{~cm}^{2}$ for Kinuhikari, respectively. Ozone was generated from oxygen-enriched dry air via an electrical discharge $\mathrm{O}_{3}$ generator (OZC-05A, Dylec Inc., Japan). The concentration of $\mathrm{O}_{3}$ in each chamber was independently and continuously monitored at 30-minute intervals with a UV absorption $\mathrm{O}_{3}$ analyzer (MODEL 1210, Dylec Inc., Japan), while the average concentration 
and $\mathrm{AOT} 40$ of $\mathrm{O}_{3}$ from 30 May to 20 September 2007 were calculated based on the monitoring data of $\mathrm{O}_{3}$ concentration in the chambers and the AOT40 was calculated as the sum of differences between the hourly mean $\mathrm{O}_{3}$ concentration and $40 \mathrm{ppb}$ when the hourly mean $\mathrm{O}_{3}$ concentration exceeded $40 \mathrm{ppb}$. The daylight AOT40 is the AOT40 during daylight hours when the solar radiation exceeded $50 \mathrm{~W} \mathrm{~m}^{-2}$. The average 7-hour $\mathrm{O}_{3}$ concentration between 10:00 and 17:00 and daylight AOT40 of $\mathrm{O}_{3}$ from 30 May to 20 September 2007 were $20 \mathrm{ppb}$ and $0.4 \mu 1 \mathrm{l}^{-1} \mathrm{~h}$ (ppm h) in the CF treatment, $58 \mathrm{ppb}$ and $15 \mathrm{ppm} \mathrm{h}$ in the $60 \mathrm{ppb} \mathrm{O}_{3}$ treatment, and $93 \mathrm{ppb}$ and $42 \mathrm{ppm}$ $\mathrm{h}$ in the $100 \mathrm{ppb} \mathrm{O}_{3}$ treatment, respectively. The daily mean, maximum and minimum air temperatures in the chambers during the exposure period of rice from 30 May to 20 September, 2007 were $23.8^{\circ} \mathrm{C}, 30.9^{\circ} \mathrm{C}$ and $19.7^{\circ} \mathrm{C}$, respectively.

\subsection{Harvest of rice leaves for biochemical analy- sis}

For biochemical analysis, leaves in different positions on the main stem, which were grown for approximately one month from the leaf emergence, were used. In the leaves of Koshihikari, the harvest date and the days from full expansion were 28 June and 21 days in the 8th leaf, 17 July and 29 days in the 10th leaf, 31 July and 28 days in the 12th leaf, and 21 August and 15 days in the 15th leaf, respectively. The 15th leaf of Koshihikari was the flag leaf. In the leaves of Kinuhikari, the harvest date and the days from full expansion were 29 June and 22 days for the 7th leaf, 18 July and 30 days for the 9th leaf, 1 August and 29 days for the 11th leaf, and 22 August and 16 days for the 14th leaf, respectively. The 14th leaf of Kinuhikari was the flag leaf. The leaves of both cultivars were harvested prior to the start of daily exposure to $\mathrm{O}_{3}$ (5:00-9:30). After the leaf area and fresh weight had been measured, the leaves were frozen in liquid nitrogen as soon as possible and then stored at $-80^{\circ} \mathrm{C}$ until use.

\subsection{Measurement of the concentrations of chlo- rophyll and total soluble protein}

To measure the concentrations of chlorophyll and total soluble protein (TSP), and the activity and concentration of Rubisco, the leaf samples $(100 \mathrm{mg}$ FW) stored at $-80^{\circ} \mathrm{C}$ were homogenized to a fine powder in liquid nitrogen with a small amount of quartzose sand. Subsequently, the leaf samples were added to an extraction buffer of $1 \mathrm{ml}$ containing 100
mM HEPES-KOH ( $\mathrm{pH}$ 8.0), 5 mM EDTA, $1 \mathrm{mM}$ dithiothreitol, $1 \mathrm{mM}$ PMSF and $20 \mathrm{mg}$ of PVPP and the crude homogenate was centrifuged at $16,000 \mathrm{~g}$ for 10 minutes at $4^{\circ} \mathrm{C}$. The supernatant of the sample was used in the assay of the concentration of TSP and the activity and concentration of Rubisco.

The concentration of chlorophyll was determined by the method of Barnes et al. (1992). After $150 \mu 1$ of the crude homogenate was added to $1,350 \mu 1$ of dimethyl sulfoxide in micro tubes, the samples were heated for one hour at $60^{\circ} \mathrm{C}$ and the absorbency of chlorophyll extracted from the leaf samples was measured at 664.9 and $648.2 \mathrm{~nm}$ with a spectrophotometer (UV-1240, Shimazu, Japan). The concentration of chlorophyll was determined by the following formulas:

$$
\begin{aligned}
& \text { Chlorophyll } a\left(\mu \mathrm{g} \mathrm{ml}^{-1}\right) \\
& \quad=\left(14.85 \times \mathrm{A}_{664.9}\right)-\left(5.14 \times \mathrm{A}_{648.2}\right) \\
& \text { Chlorophyll } b\left(\mu \mathrm{g} \mathrm{m}^{-1}\right) \\
& \quad=\left(25.48 \times \mathrm{A}_{648.2}\right)-\left(7.36 \times \mathrm{A}_{664.9}\right) \\
& \text { Chlorophyll } a+b\left(\mu \mathrm{g} \mathrm{ml}^{-1}\right) \\
& \quad=\left(7.49 \times \mathrm{A}_{664.9}\right)-\left(20.34 \times \mathrm{A}_{648.2}\right)
\end{aligned}
$$

The concentration of TSP was determined by the Bradford dye-binding procedure (Bradford 1976). To measure TSP, $30 \mu 1$ of supernatant of the sample was added to $4.5 \mathrm{ml}$ of dye solution containing $0.01 \%$ (w/v) CBB G-250, 5\% (v/v) ethanol and 8.5\% (v/v) phosphoric acid. The absorbency of the sample was measured at $595 \mathrm{~nm}$ within 5-30 minutes using a spectrophotometer. In the quantification of TSP, a calibration curve of the protein concentration was made with bovine serum albumin (BSA).

\subsection{Measurement of the activity and concentra- tion of Rubisco}

The activity of Rubisco was determined by the modified method of Tissue et al. (1993). To measure Rubisco activity, the supernatant was applied to the PD-10 desalting column filled with Sephadex G-25 to desalt the supernatant, while to determine the initial activity of Rubisco, immediately after combining the desalted sample solution $(150 \mu 1)$ with an assay solution $(830 \mu \mathrm{l})$ containing $50 \mathrm{mM}$ HEPES-KOH $(\mathrm{pH} 8.0), 10$ $\mathrm{mM} \mathrm{NaHCO}$, $0.2 \mathrm{mM}$ NADH, $2.5 \mathrm{mM}$ ATP, $10 \mathrm{mM}$ $\mathrm{KCl}, 1 \mathrm{mM}$ EDTA, $20 \mathrm{mM} \mathrm{MgCl} 2,5 \mathrm{mM}$ DTT, $5 \mathrm{mM}$ phosphocreatine, 6 units $\mathrm{ml}^{-1}$ phosphoglyceric kinase, 6 units $\mathrm{ml}^{-1}$ glyceraldehyde 3-phosphate dehydrogenase and 20 units $\mathrm{ml}^{-1}$ phosphocreatine kinase at the final 
concentration, the reaction was started by adding $20 \mu 1$ of $30 \mathrm{mM}$ RubP. The change in the absorption of the reaction solution at $340 \mathrm{~nm}$ over 1 minute was measured for approximately 20 seconds after the addition of RubP with a spectrophotometer and the activity of Rubisco was calculated using the extinction coefficient, $6.22 \mathrm{mM}^{-1} \mathrm{~cm}^{-1}$. In the present study, Rubisco activity was expressed as $\mu \mathrm{mol}$ of NADPH m $\mathrm{m}^{-2} \mathrm{~s}^{-1}$.

To measure the concentration of Rubisco, $50 \mu 1$ of the supernatant of the sample was added to the extraction buffer, $100 \mu 1$ of Laemmli buffer containing $0.1 \mathrm{M}$ Tris- $\mathrm{HCl}$ (pH 6.8), 20\% (w/v) glycerol, 4\% (w/v) sodium dodecylsulfate (SDS) and $0.004 \%$ bromophenol blue, and $20 \mu 1$ of 2-mercaptoethanol according to the modified method of Laemmli (1970). After heating at $95^{\circ} \mathrm{C}$ for 5 minutes, the sample was used for SDSPAGE. The Rubisco protein was separated by SDSPAGE using a $1 \mathrm{~mm}$ thick polyacrylamide gel (13\% separating, 4\% stacking) and the amount of Rubisco was calculated based on the density of CBB-stained subunit bands scanned with a gel image analysis system (densitograph, AE-6920MF, ATTO Co., Japan). In the quantification of Rubisco, calibration curve of the protein concentration was made with BSA.

\subsection{Measurement of the activity of radical scaveng- ing enzymes}

To measure the activities of SOD, CAT and GR, the leaf samples $(100 \mathrm{mg} \mathrm{FW})$ stored at $-80^{\circ} \mathrm{C}$ were homogenized to a fine powder in liquid nitrogen with a small amount of quartzose sand. Subsequently, the leaf samples were added to $1 \mathrm{ml}$ of extraction buffer containing $50 \mathrm{mM}$ potassium phosphate $(\mathrm{pH} 7.8)$ and $1 \mathrm{mM} \mathrm{Na-EDTA}$, and $20 \mathrm{mg}$ of PVPP. The crude homogenate was centrifuged at $16,000 \mathrm{~g}$ for 10 minutes at $4^{\circ} \mathrm{C}$, while the supernatant of the sample was used in the assay of the activities of SOD, CAT and GR.

The activity of SOD was determined by the methods of McCord and Fridovich (1969). The supernatant (70 $\mu 1)$ was added to $0.8 \mathrm{ml}$ of $50 \mathrm{mM}$ potassium phosphate buffer ( $\mathrm{pH}$ 7.8) containing $0.1 \mathrm{mM}$ EDTA, $0.1 \mathrm{ml}$ of $1 \mathrm{mM}$ xanthine solution and $10 \mu 1$ of $1 \mathrm{mM}$ cytochrome $c$ (horse heart, Sigma-Aldrich). After the measurement of blank at $550 \mathrm{~nm}$ for 1 minute with a spectrophotometer, $20 \mu 1$ of xanthine oxidase solution (from bovine milk, 4.0 units $\mathrm{ml}^{-1}$, Sigma-Aldrich) was added and subsequently, the absorbance was measured for 2 minutes at $550 \mathrm{~nm}$. In the present study, 1 unit of SOD activity was defined as the amount of enzyme required to inhibit ferricytochrome $c$ reduction by $50 \%$.

The activity of CAT was determined by the method of Aebi (1983). The supernatant $(20 \mu 1)$ was added to $970 \mu 1$ of $50 \mathrm{mM}$ potassium phosphate buffer ( $\mathrm{pH} 7.8$ ) containing $1 \mathrm{mM}$ EDTA. Following the measurement of blank at $240 \mathrm{~nm}$ for 1 minute with a spectrophotometer, $10 \mu 1$ of $880 \mathrm{mM} \mathrm{H}_{2} \mathrm{O}_{2}$ was added, whereupon the absorbance was measured for 2 minutes at $240 \mathrm{~nm}$ and the activity of CAT was calculated using the extinction coefficient, $40 \mathrm{mM}^{-1} \mathrm{~cm}^{-1}$. In the present study, CAT activity was expressed as mmol of $\mathrm{H}_{2} \mathrm{O}_{2} \mathrm{~m}^{-2} \mathrm{~s}^{-1}$.

The activity of GR was determined by the method of Foyer and Halliwell (1976). The supernatant $(50 \mu 1)$ was added to $850 \mu 1$ of $50 \mathrm{mM}$ potassium phosphate buffer (pH 7.8) containing $0.1 \mathrm{mM}$ EDTA and $50 \mu 1$ of $2 \mathrm{mM}$ NADPH. After the measurement of blank at $340 \mathrm{~nm}$ for 1 minute with a spectrophotometer, $50 \mu 1$ of $10 \mathrm{mM}$ oxidized glutathione (GSSG) was added. Subsequently, the absorbance was measured for 2 minutes at $340 \mathrm{~nm}$. The GR activity was calculated using the extinction coefficient, $6.22 \mathrm{mM}^{-1} \mathrm{~cm}^{-1}$. In the present study, GR activity was expressed as $\mu \mathrm{mol}$ of NADPH $\mathrm{m}^{-2} \mathrm{~s}^{-1}$.

To measure the activity of APX, leaf samples $(50 \mathrm{mg}$ $\mathrm{FW}$ ), which were stored at $-80^{\circ} \mathrm{C}$, were homogenized to a fine powder in liquid nitrogen with a small amount of quartzose sand. Subsequently, leaf samples were added to an extraction buffer of $0.5 \mathrm{ml}$ containing $50 \mathrm{mM}$ potassium phosphate ( $\mathrm{pH}$ 7.0), $1 \mathrm{mM} \mathrm{Na-EDTA}$ and 5 $\mathrm{mM}$ L-ascorbic acid, and $10 \mathrm{mg}$ of PVPP. The crude homogenate was centrifuged at $16,000 \mathrm{~g}$ for 10 minutes at $4^{\circ} \mathrm{C}$, while the supernatant of the sample was used in the assay of the activity of APX. The activity of APX was determined by the method of Nakano and Asada (1981). The supernatant $(20 \mu 1)$ was added to $910 \mu 1$ of $50 \mathrm{mM}$ potassium phosphate buffer ( $\mathrm{pH}$ 7.0) and $50 \mu 1$ of $5 \mathrm{mM} \mathrm{L}$-ascorbic acid solution. After the measurement of blank at $290 \mathrm{~nm}$ for 1 minute with a spectrophotometer, $20 \mu 1$ of $50 \mathrm{mM} \mathrm{H}_{2} \mathrm{O}_{2}$ was added, whereupon the absorbance was measured for 2 minutes at $290 \mathrm{~nm}$ and the activity of APX was calculated using the extinction coefficient, $2.8 \mathrm{mM}^{-1} \mathrm{~cm}^{-1}$. In the present study, the activity of APX was expressed as $\mu \mathrm{mol}$ of ascorbate $\mathrm{m}^{-2} \mathrm{~s}^{-1}$.

When measuring the activities of MDAR and DHAR, the leaf samples (50 $\mathrm{mg} F W$ ) stored at $-80^{\circ} \mathrm{C}$ were homogenized to a fine powder in liquid nitrogen with a small amount of quartzose sand. Subsequently, these were added to an extraction buffer 
of $0.5 \mathrm{ml}$ containing $50 \mathrm{mM}$ Tris- $\mathrm{HCl}(\mathrm{pH}$ 7.0), $1 \mathrm{mM}$ L-ascorbic acid, $1 \mathrm{mM}$ dithiothreitol, $1 \mathrm{mM}$ EDTA, 1 $\mathrm{mM}$ glutathione reduced form and $5 \mathrm{mM}$ magnesium chloride, and $10 \mathrm{mg}$ of PVPP. The crude homogenate was centrifuged at $12,000 \mathrm{~g}$ for 6 minutes at $4^{\circ} \mathrm{C}$ and $20,000 \mathrm{~g}$ for 16 minutes at $4^{\circ} \mathrm{C}$ and the supernatant of the sample was used in the assay of the activities of MDAR and DHAR.

The activity of MDAR was determined by the method of Hossain et al. (1984). The supernatant $(100 \mu \mathrm{l})$ was added to $500 \mu \mathrm{l}$ of $100 \mathrm{mM}$ Tris-HCl buffer ( $\mathrm{pH} 7.5$ ), $100 \mu 1$ of $25 \mathrm{mM} \mathrm{L-ascorbic} \mathrm{acid}$ solution, $50 \mu 1$ of $4 \mathrm{mM}$ NADPH and $249 \mu 1$ of deionized water. After the measurement of blank at $340 \mathrm{~nm}$ for 1 minute with a spectrophotometer, $1 \mu 1$ of ascorbate oxidase ( 0.15 units $\mu 1^{-1}$, Sigma-Aldrich) was added. Subsequently, the absorbance was measured for 3 minutes at $340 \mathrm{~nm}$. The activity of MDAR was calculated using the extinction coefficient, 6.22 $\mathrm{mM}^{-1} \mathrm{~cm}^{-1}$. In the present study, MDAR activity was expressed as $\mu \mathrm{mol}$ of NADPH m $\mathrm{m}^{-2} \mathrm{~s}^{-1}$.

The activity of DHAR was determined by the method of Hossain and Asada (1984). The supernatant $(2 \mu 1)$ was added to $500 \mu 1$ of $100 \mathrm{mM}$ potassium phosphate buffer ( $\mathrm{pH} 6.5$ ), $423 \mu 1$ of deionized water and $25 \mu 1$ of $200 \mathrm{mM}$ reduced glutathione. After the measurement of the blank at $265 \mathrm{~nm}$ for 1 minute with a spectrophotometer, $50 \mu 1$ of oxidized glutathione was added, whereupon the absorbance was measured for 2 minutes at $265 \mathrm{~nm}$ and the DHAR activity was calculated using the extinction coefficient, 14.3 $\mathrm{mM}^{-1} \mathrm{~cm}^{-1}$. In the present study, DHAR activity was expressed in the form of $\mu \mathrm{mol}$ of dehydroascorbate $\mathrm{m}^{-2} \mathrm{~s}^{-1}$.

\subsection{Measurement of the concentration and redox state of antioxidants}

To measure the concentrations of ascorbate and glutathione, the leaf samples (50 mg FW) stored at $-80^{\circ} \mathrm{C}$ were homogenized to a fine powder in liquid nitrogen with a small amount of quartzose sand. Subsequently, the leaf samples were added to $2.5 \mathrm{ml}$ of $5 \%(\mathrm{w} / \mathrm{v})$ metaphosphoric acid buffer and $10 \mathrm{mg}$ of PVPP and the crude homogenate was centrifuged at $15,000 \mathrm{~g}$ for 20 minutes at $4^{\circ} \mathrm{C}$. The supernatant of the sample was also used in an assay of the concentrations of ascorbate and glutathione.

The concentration of ascorbate was determined by the modified method of Luwe and Heber (1995). To measure the concentration of reduced ascorbate, the supernatant $(25 \mu 1)$ was added to $974 \mu 1$ of 100 $\mathrm{mM}$ potassium phosphate buffer $(\mathrm{pH} 7.0)$. After the measurement of a blank at $265 \mathrm{~nm}$ for 1 minute with a spectrophotometer, $1 \mu 1$ of ascorbate oxidase (1 unit $\mu 1^{-1}$, Sigma-Aldrich) was added, whereupon the absorbance was measured for 2 minutes at $265 \mathrm{~nm}$. To measure the concentration of oxidized ascorbate, the supernatant $(50 \mu 1)$ was added to $949 \mu 1$ of 100 $\mathrm{mM}$ potassium phosphate buffer ( $\mathrm{pH}$ 7.7). Following the measurement of a blank at $265 \mathrm{~nm}$ for 1 minute with a spectrophotometer, $1 \mu 1$ of $200 \mathrm{mM}$ dithiothreitol (DTT) was added, whereupon the absorbance was measured for 5 minutes at $265 \mathrm{~nm}$. In the present study, the concentration of reduced ascorbate was calculated using the extinction coefficient, $14.3 \mathrm{mM}^{-1}$ $\mathrm{cm}^{-1}$. The redox state of ascorbate was expressed in the form of the concentration ratio of reduced ascorbate to total ascorbate (the sum of the reduced and oxidized forms of ascorbate).

The concentration of glutathione was determined by the method of Griffith (1980). To measure the concentration of total glutathione (the sum of the reduced and oxidized forms of glutathione), the supernatant $(195 \mu 1)$ was added to $660 \mu 1$ of $125 \mathrm{mM}$ potassium phosphate containing $6.3 \mathrm{mM}$ Na-EDTA, $100 \mu 1$ of 6 $\mathrm{mM} \mathrm{5,5}$ '-dithiobis (2-nitrobenzoic acid) and $40 \mu 1$ of $5 \mathrm{mM}$ NADPH. After the measurement of blank at $412 \mathrm{~nm}$ for 1 minute with a spectrophotometer, $5 \mu 1$ of glutathione reductase (from baker's yeast, 1.81 units $\mu 1^{-1}$, Sigma-Aldrich) was added. Subsequently, the absorbance was measured for 2 minutes at $412 \mathrm{~nm}$. In the quantification of total glutathione concentration, a calibration curve was constructed, based on the concentrations of the reduced and oxidized forms of glutathione. To measure the concentration of oxidized glutathione, the supernatant $(1 \mathrm{ml})$ was added to $20 \mu 1$ of 2-vinylpyridine. Following incubation at $25^{\circ} \mathrm{C}$ for 40 minutes, the absorbance of the sample was measured at $412 \mathrm{~nm}$ for 1 minute with a spectrophotometer and the concentration of reduced glutathione was calculated by subtracting the oxidized glutathione concentration from the total glutathione concentration. The redox state of glutathione was expressed in the form of the ratio of reduced glutathione concentration to the total glutathione concentration.

\subsection{Calculation of the $\mathrm{O}_{3}$ exposure-response re- lationship}

The mean daylight AOT40 of the three chamber replicates in each of the gas treatments from 30 May to 
20 September, 2007 was used as the $\mathrm{O}_{3}$ exposure index in calculating the $\mathrm{O}_{3}$ exposure-response relationship. The average activity of radical scavenging enzymes in the $\mathrm{CF}$ treatment was also used as a reference $(100 \%)$ in each chamber to calculate the relative enzyme activity for each $\mathrm{O}_{3}$ treatment. To calculate the coefficient of determination value $\left(R^{2}\right)$ and $P$ value for the slope, a single regression line was obtained from the relationship between the relative activity of radical scavenging enzymes in the leaves within approximately one month of emergence, and the mean daylight AOT40 of $\mathrm{O}_{3}$.

\subsection{Statistical analyses}

Statistical analyses were performed with the SPSS ${ }^{\circledR}$ statistical package. Analysis of variance (ANOVA) was used to test the effects of $\mathrm{O}_{3}$ and cultivars. When a significant combined effect of $\mathrm{O}_{3}$ and cultivars was detected, Tukey's HSD test was performed to identify

Table 1. Effects of $\mathrm{O}_{3}$ on the concentration of chlorophyll and activity and concentration of Rubisco in leaves of rice (Oryza sativa L.).

\begin{tabular}{|c|c|c|c|c|}
\hline Cultivar & Treatment & $\begin{array}{l}\text { Concentration of } \\
\text { chlorophyll }\left(\mathrm{g} \mathrm{m}^{-2}\right)\end{array}$ & $\begin{array}{l}\text { Activity of Rubisco } \\
\qquad\left(\mu \mathrm{mol} \mathrm{m} \mathrm{m}^{-2} \mathrm{~s}^{-1}\right)\end{array}$ & $\begin{array}{l}\text { Concentration of } \\
\text { Rubisco }\left(\mathrm{g} \mathrm{m}^{-2}\right)\end{array}$ \\
\hline \multirow[t]{3}{*}{ Koshihikari (8th leaf) } & $\mathrm{CF}$ & $0.228(0.001)$ & $7.0(0.5)$ & $2.05(0.37)$ \\
\hline & $60 \mathrm{ppb} \mathrm{O}_{3}$ & $0.213(0.015)$ & $6.6(0.3)$ & $1.83(0.35)$ \\
\hline & $100 \mathrm{ppb} \mathrm{O}_{3}$ & $0.200(0.019)$ & $6.0(0.9)$ & $1.79(0.14)$ \\
\hline \multirow[t]{3}{*}{ Kinuhikari (7th leaf) } & $\mathrm{CF}$ & $0.228(0.008)$ & $7.3(0.8)$ & $2.04(0.28)$ \\
\hline & $60 \mathrm{ppb} \mathrm{O}_{3}$ & $0.211(0.014)$ & $6.3(1.3)$ & $1.80(0.22)$ \\
\hline & $100 \mathrm{ppb} \mathrm{O}_{3}$ & $0.200(0.016)$ & $6.5(1.1)$ & $1.99(0.28)$ \\
\hline \multirow[t]{3}{*}{ ANOVA } & $\mathrm{O}_{3}$ & $*$ & n.s. & n.s. \\
\hline & Cultivar & n.s. & n.s. & n.s. \\
\hline & $\mathrm{O}_{3} \times$ Cultivar & n.s. & n.s. & n.s. \\
\hline \multirow[t]{3}{*}{ Koshihikari (10th leaf) } & $\mathrm{CF}$ & $0.269(0.006)$ & $15.2(1.1) \mathrm{a}$ & $1.80(0.12)$ \\
\hline & $60 \mathrm{ppb} \mathrm{O}_{3}$ & $0.248(0.013)$ & $14.1(0.7) \mathrm{a}$ & $1.60(0.14)$ \\
\hline & $100 \mathrm{ppb} \mathrm{O}_{3}$ & $0.226(0.005)$ & $13.4(1.1) \mathrm{a}$ & $1.44(0.06)$ \\
\hline \multirow[t]{3}{*}{ Kinuhikari (9th leaf) } & $\mathrm{CF}$ & $0.233(0.014)$ & $13.7(1.2) \mathrm{a}$ & $1.40(0.05)$ \\
\hline & $60 \mathrm{ppb} \mathrm{O}_{3}$ & $0.220(0.009)$ & $13.9(1.8) \mathrm{a}$ & $1.34(0.07)$ \\
\hline & $100 \mathrm{ppb} \mathrm{O}_{3}$ & $0.210(0.009)$ & $13.8(1.5) \mathrm{a}$ & $1.36(0.06)$ \\
\hline \multirow[t]{3}{*}{ ANOVA } & $\mathrm{O}_{3}$ & $* *$ & n.s. & n.s. \\
\hline & Cultivar & $*$ & n.s. & $* *$ \\
\hline & $\mathrm{O}_{3} \times$ Cultivar & n.s. & $*$ & n.s. \\
\hline \multirow[t]{3}{*}{ Koshihikari (Flag leaf) } & $\mathrm{CF}$ & $0.177(0.002)$ & $5.7(0.3)$ & $0.76(0.04)$ \\
\hline & $60 \mathrm{ppb} \mathrm{O}_{3}$ & $0.177(0.004)$ & $6.4(1.1)$ & $0.92(0.19)$ \\
\hline & $100 \mathrm{ppb} \mathrm{O}_{3}$ & $0.181(0.005)$ & $7.8(1.0)$ & $0.95(0.06)$ \\
\hline \multirow[t]{3}{*}{ Kinuhikari (Flag leaf) } & $\mathrm{CF}$ & $0.179(0.014)$ & $7.5(0.6)$ & $1.01(0.10)$ \\
\hline & $60 \mathrm{ppb} \mathrm{O}_{3}$ & $0.184(0.007)$ & $7.9(0.6)$ & $0.99(0.06)$ \\
\hline & $100 \mathrm{ppb} \mathrm{O}_{3}$ & $0.181(0.012)$ & $8.7(0.3)$ & $1.09(0.08)$ \\
\hline \multirow[t]{3}{*}{ ANOVA } & $\mathrm{O}_{3}$ & n.s. & * & n.s. \\
\hline & Cultivar & n.s. & $*$ & $* *$ \\
\hline & $\mathrm{O}_{3} \times$ Cultivar & n.s. & n.s. & n.s. \\
\hline
\end{tabular}

The plants were exposed daily to charcoal-filtered air (CF) or $\mathrm{O}_{3}$ at $60 \mathrm{ppb}$ or $100 \mathrm{ppb}$ (10:00-17:00) from 30 May to 21 August 2007. Each value is the mean of 3 chamber replicates, and the standard deviation is shown in parentheses.

Two-way ANOVA: $* P<0.05, * * P<0.01$, n.s. $=$ not significant

When a significant combined effect of $\mathrm{O}_{3}$ and cultivar was detected, Turkey's HSD test was performed to identify significant differences among the 6 treatments. Values with different letters are significantly different at $P<0.05$. 
Table 2. Effects of $\mathrm{O}_{3}$ on the activity of radical scavenging enzymes in leaves of rice (Oryza sativa L.).

\begin{tabular}{|c|c|c|c|c|c|c|c|}
\hline Cultivar & Treatment & $\begin{array}{c}\text { SOD } \\
\left(\mathrm{U} \mathrm{cm}^{-2}\right)\end{array}$ & $\begin{array}{c}\text { CAT } \\
(\mathrm{mmol} \\
\left.\mathrm{m}^{-2} \mathrm{~s}^{-1}\right)\end{array}$ & $\begin{array}{c}\mathrm{APX} \\
(\mu \mathrm{mol} \\
\left.\mathrm{m}^{-2} \mathrm{~s}^{-1}\right)\end{array}$ & $\begin{array}{l}\text { MDAR } \\
(\mu \mathrm{mol} \\
\left.\mathrm{m}^{-2} \mathrm{~s}^{-1}\right)\end{array}$ & $\begin{array}{l}\text { DHAR } \\
(\mu \text { mol } \\
\left.\mathrm{m}^{-2} \mathrm{~s}^{-1}\right)\end{array}$ & $\begin{array}{c}\mathrm{GR} \\
(\mu \mathrm{mol} \\
\left.\mathrm{m}^{-2} \mathrm{~s}^{-1}\right)\end{array}$ \\
\hline Koshihikari & $\mathrm{CF}$ & $14.8(0.6) \mathrm{a}$ & $12.4(0.5)$ & $13.8(0.9)$ & $0.16(0.04)$ & $16.9(0.8)$ & $1.6(0.2) \mathrm{a}$ \\
\hline (8th leaf) & 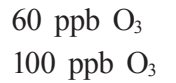 & $\begin{array}{l}13.9(0.4) \mathrm{a} \\
13.2(2.5) \mathrm{a}\end{array}$ & $\begin{array}{l}11.6(0.1) \\
10.0(1.3)\end{array}$ & $\begin{array}{l}15.2(2.0) \\
17.9(3.0)\end{array}$ & $\begin{array}{l}0.20(0.01) \\
0.20(0.00)\end{array}$ & $\begin{array}{l}12.6(0.1) \\
10.1(1.5)\end{array}$ & $\begin{array}{l}1.6(0.1) \mathrm{a} \\
2.0(0.2) \mathrm{a}\end{array}$ \\
\hline $\begin{array}{l}\text { Kinuhikari } \\
\text { (7th leaf) }\end{array}$ & 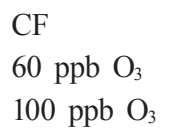 & $\begin{array}{l}13.9(1.9) \mathrm{a} \\
13.5(1.2) \mathrm{a} \\
15.5(2.1) \mathrm{a}\end{array}$ & $\begin{array}{l}11.9(0.4) \\
11.4(0.9) \\
8.4(0.5)\end{array}$ & $\begin{array}{l}15.6(0.9) \\
17.2(1.3) \\
19.4(2.1)\end{array}$ & $\begin{array}{l}0.13(0.01) \\
0.19(0.03) \\
0.22(0.04)\end{array}$ & $\begin{array}{l}11.2(0.7) \\
9.7(1.0) \\
8.2(1.2)\end{array}$ & $\begin{array}{l}1.6(0.1) \mathrm{a} \\
1.8(0.1) \mathrm{a} \\
1.9(0.1) \mathrm{a}\end{array}$ \\
\hline ANOVA & $\begin{array}{l}\mathrm{O}_{3} \\
\text { Cultivar } \\
\mathrm{O}_{3} \times \text { Cultivar }\end{array}$ & $\begin{array}{c}\text { n.s. } \\
\text { n.s. } \\
*\end{array}$ & $\begin{array}{c}* * \\
\text { n.s. } \\
\text { n.s. }\end{array}$ & $\begin{array}{l}* * \\
\text { n.s. } \\
\text { n.s. }\end{array}$ & $\begin{array}{c}* \\
\text { n.s. } \\
\text { n.s. }\end{array}$ & $\begin{array}{c}* \\
* \\
\text { n.s. } \\
\end{array}$ & $\begin{array}{c}* \\
\text { n.s. } \\
*\end{array}$ \\
\hline $\begin{array}{l}\text { Koshihikari } \\
\text { (10th leaf) }\end{array}$ & $\begin{array}{l}\mathrm{CF} \\
60 \mathrm{ppb} \mathrm{O}_{3} \\
100 \mathrm{ppb} \mathrm{O}_{3}\end{array}$ & $\begin{array}{l}14.6(0.3) \\
14.8(1.0) \\
15.1(0.6)\end{array}$ & $\begin{array}{l}8.4(0.5) \\
8.6(0.9) \\
8.2(0.3)\end{array}$ & $\begin{array}{l}13.8(1.5) \\
12.6(0.8) \\
14.7(1.2)\end{array}$ & $\begin{array}{ll}0.07 & (0.00) \\
0.11 & (0.01) \\
0.13 & (0.01)\end{array}$ & $\begin{array}{l}10.9(0.8) \\
9.7(1.1) \\
7.2(1.2)\end{array}$ & $\begin{array}{ll}1.2 & (0.08) \\
1.5 & (0.22) \\
1.6 & (0.03)\end{array}$ \\
\hline $\begin{array}{l}\text { Kinuhikari } \\
\text { (9th leaf) }\end{array}$ & $\begin{array}{l}\mathrm{CF} \\
60 \mathrm{ppb} \mathrm{O}_{3} \\
100 \mathrm{ppb} \mathrm{O}_{3}\end{array}$ & $\begin{array}{l}13.8(1.0) \\
13.6(0.5) \\
13.7(1.2)\end{array}$ & $\begin{array}{l}7.0(0.3) \\
7.0(0.7) \\
7.0(0.5)\end{array}$ & $\begin{array}{l}12.0(1.0) \\
12.6(0.4) \\
14.8(1.1)\end{array}$ & $\begin{array}{l}0.08(0.02) \\
0.12(0.04) \\
0.15(0.02)\end{array}$ & $\begin{array}{l}11.2(1.0) \\
8.6(1.7) \\
7.4(2.2)\end{array}$ & $\begin{array}{ll}1.3 & (0.06) \\
1.3 & (0.03) \\
1.7 & (0.08)\end{array}$ \\
\hline ANOVA & $\begin{array}{l}\mathrm{O}_{3} \\
\text { Cultivar } \\
\mathrm{O}_{3} \times \text { Cultivar }\end{array}$ & $\begin{array}{l}\text { n.s. } \\
* * \\
\text { n.s. }\end{array}$ & $\begin{array}{c}\text { n.s. } \\
* \\
\text { n.s. }\end{array}$ & $\begin{array}{l}* \\
\text { n.s. } \\
\text { n.s. }\end{array}$ & $\begin{array}{l}* \\
\text { n.s. } \\
\text { n.s. }\end{array}$ & $\begin{array}{l}* \\
\text { n.s. } \\
\text { n.s. }\end{array}$ & $\begin{array}{l}* * \\
\text { n.s. } \\
\text { n.s. }\end{array}$ \\
\hline $\begin{array}{l}\text { Koshihikari } \\
\text { (12th leaf) }\end{array}$ & $\begin{array}{l}\mathrm{CF} \\
60 \mathrm{ppb} \mathrm{O} \\
100 \mathrm{ppb} \mathrm{O}_{3}\end{array}$ & $\begin{array}{l}14.1(0.7) \\
14.3(0.3) \\
13.2(0.5)\end{array}$ & $\begin{array}{l}6.36(0.5) \\
7.71(1.0) \\
7.39(0.2)\end{array}$ & $\begin{array}{l}11.7(0.5) \\
12.5(0.8) \\
14.7(1.5)\end{array}$ & $\begin{array}{l}0.10(0.02) \\
0.09(0.01) \\
0.14(0.02)\end{array}$ & $\begin{array}{l}13.5(1.2) \\
12.7(1.8) \\
10.6(0.9)\end{array}$ & $\begin{array}{ll}0.8 & (0.07) \\
0.9 & (0.12) \\
1.0 & (0.09)\end{array}$ \\
\hline $\begin{array}{l}\text { Kinuhikari } \\
\text { (11th leaf) }\end{array}$ & $\begin{array}{l}\mathrm{CF} \\
60 \mathrm{ppb} \mathrm{O}_{3} \\
100 \mathrm{ppb} \mathrm{O}_{3}\end{array}$ & $\begin{array}{l}13.3(1.4) \\
12.8(0.5) \\
12.5(1.9)\end{array}$ & $\begin{array}{l}6.25(0.8) \\
7.37(0.6) \\
6.30(0.4)\end{array}$ & $\begin{array}{l}10.9(0.6) \\
11.6(1.3) \\
14.2(0.9)\end{array}$ & $\begin{array}{l}0.13(0.01) \\
0.14(0.02) \\
0.17(0.02)\end{array}$ & $\begin{array}{l}13.7(0.5) \\
11.6(1.0) \\
8.4(1.2)\end{array}$ & $\begin{array}{ll}1.0 & (0.06) \\
1.0 & (0.09) \\
1.3 & (0.13)\end{array}$ \\
\hline ANOVA & $\begin{array}{l}\mathrm{O}_{3} \\
\text { Cultivar } \\
\mathrm{O}_{3} \times \text { Cultivar }\end{array}$ & $\begin{array}{l}\text { n.s. } \\
\text { n.s. } \\
\text { n.s. }\end{array}$ & $\begin{array}{c}* \\
\text { n.s. } \\
\text { n.s. }\end{array}$ & $\begin{array}{l}* * \\
\text { n.s. } \\
\text { n.s. }\end{array}$ & $\begin{array}{l}* * \\
\text { n.s. } \\
\text { n.s. }\end{array}$ & $\begin{array}{l}* * * \\
\text { n.s. } \\
\text { n.s. }\end{array}$ & $\begin{array}{l}* * \\
\text { n.s. } \\
\text { n.s. }\end{array}$ \\
\hline $\begin{array}{l}\text { Koshihikari } \\
\text { (Flag leaf) }\end{array}$ & $\begin{array}{l}\mathrm{CF} \\
60 \mathrm{ppb} \mathrm{O}_{3} \\
100 \mathrm{ppb} \mathrm{O}_{3}\end{array}$ & $\begin{array}{l}11.2(0.9) \\
11.9(0.6) \\
11.7(0.2)\end{array}$ & $\begin{array}{l}3.73(0.2) \\
4.04(0.1) \\
4.93(0.3)\end{array}$ & $\begin{array}{l}8.4(0.4) \\
8.8(0.7) \\
10.6(1.4)\end{array}$ & $\begin{array}{l}0.06(0.01) \\
0.08(0.02) \\
0.16(0.02)\end{array}$ & $\begin{array}{l}13.8(0.4) \\
16.6(2.5) \\
15.2(2.1)\end{array}$ & $\begin{array}{ll}0.8 & (0.17) \\
0.7 & (0.11) \\
1.1 & (0.24)\end{array}$ \\
\hline $\begin{array}{l}\text { Kinuhikari } \\
\text { (Flag leaf) }\end{array}$ & $\begin{array}{l}\mathrm{CF} \\
60 \mathrm{ppb} \mathrm{O}_{3} \\
100 \mathrm{ppb} \mathrm{O}_{3}\end{array}$ & $\begin{array}{l}12.5(0.9) \\
11.9(0.3) \\
12.4(0.2)\end{array}$ & $\begin{array}{l}4.42(0.4) \\
4.98(0.6) \\
5.84(0.3)\end{array}$ & $\begin{array}{l}11.5(0.5) \\
10.5(0.5) \\
13.6(0.8)\end{array}$ & $\begin{array}{l}0.09(0.00) \\
0.10(0.02) \\
0.19(0.02)\end{array}$ & $\begin{array}{l}15.1(2.1) \\
16.3(1.7) \\
18.1\end{array}$ & $\begin{array}{l}1.0(0.09) \\
1.1(0.04) \\
1.4(0.13)\end{array}$ \\
\hline ANOVA & $\begin{array}{l}\mathrm{O}_{3} \\
\text { Cultivar } \\
\mathrm{O}_{3} \times \text { Cultivar }\end{array}$ & $\begin{array}{l}\text { n.s. } \\
\text { n.s. } \\
\text { n.s. }\end{array}$ & $\begin{array}{c}* \\
* \\
\text { n.s. }\end{array}$ & $\begin{array}{c}* * \\
* \\
\text { n.s. }\end{array}$ & $\begin{array}{l}* * \\
\text { n.s. } \\
\text { n.s. }\end{array}$ & $\begin{array}{l}\text { n.s. } \\
\text { n.s. } \\
\text { n.s. }\end{array}$ & $\begin{array}{c}* \\
* \\
\text { n.s. }\end{array}$ \\
\hline
\end{tabular}

The plants were exposed daily to charcoal-filtered air (CF) or $\mathrm{O}_{3}$ at $60 \mathrm{ppb}$ or $100 \mathrm{ppb}$ (10:00-17:00) from 30 May to 21 August 2007. Each value is the mean of 3 chamber replicates, and the standard deviation is shown in parentheses.

Two-way ANOVA: $* P<0.05, * * P<0.01, * * * P<0.001$, n.s. $=$ not significant

When a significant combined effect of $\mathrm{O}_{3}$ and cultivar was detected, Turkey's HSD test was performed to identify significant differences among the 6 treatments. Values with different letters are significantly different at $P<0.05$. 
Table 3. Effects of $\mathrm{O}_{3}$ on the concentrations and redox states of ascorbate and glutathione in leaves of rice (Oryza sativa L.).

\begin{tabular}{|c|c|c|c|c|c|}
\hline Cultivar & Treatment & $\begin{array}{c}\text { Ascorbate } \\
\text { concentration } \\
\left.(\mathrm{mmol} \mathrm{m})^{-2}\right)\end{array}$ & $\begin{array}{l}\text { Ascorbate } \\
\text { redox } \\
\text { state }(\%)\end{array}$ & $\begin{array}{l}\text { Glutathione } \\
\text { concentration } \\
\left(\mathrm{mmol} \mathrm{m}{ }^{-2}\right)\end{array}$ & $\begin{array}{c}\text { Glutathione } \\
\text { redox } \\
\text { state }(\%)\end{array}$ \\
\hline \multirow{3}{*}{$\begin{array}{l}\text { Koshihikari } \\
\text { (8th leaf) }\end{array}$} & $\mathrm{CF}$ & $0.801(0.027)$ & 86.9 (2.7) & $0.198(0.015)$ & $84.4(7.5)$ \\
\hline & $60 \mathrm{ppb} \mathrm{O}_{3}$ & $0.858(0.063)$ & 86.5 (1.7) & $0.180(0.007)$ & $85.6(4.3)$ \\
\hline & $100 \mathrm{ppb} \mathrm{\textrm {O } _ { 3 }}$ & $0.877(0.079)$ & 84.5 (4.9) & $0.209(0.056)$ & $82.4(4.5)$ \\
\hline \multirow{3}{*}{$\begin{array}{l}\text { Kinuhikari } \\
\text { (7th leaf) }\end{array}$} & $\mathrm{CF}$ & $0.824(0.026)$ & $87.6(1.2)$ & $0.206(0.027)$ & $95.4(1.6)$ \\
\hline & $60 \mathrm{ppb} \mathrm{O}_{3}$ & $0.863(0.030)$ & $85.7(0.3)$ & $0.176(0.021)$ & $93.8(3.6)$ \\
\hline & $100 \mathrm{ppb} \mathrm{\textrm {O } _ { 3 }}$ & $0.817(0.021)$ & $86.6(0.1)$ & $0.175(0.038)$ & $95.5(2.8)$ \\
\hline \multirow[t]{3}{*}{ ANOVA } & $\mathrm{O}_{3}$ & n.s. & n.s. & n.s. & n.s. \\
\hline & Cultivar & n.s. & n.s. & n.s. & $*$ \\
\hline & $\mathrm{O}_{3} \times$ Cultivar & n.s. & n.s. & n.s. & n.s. \\
\hline \multirow{3}{*}{$\begin{array}{l}\text { Koshihikari } \\
\text { (10th leaf) }\end{array}$} & $\mathrm{CF}$ & $0.544(0.019)$ & $79.2(1.3)$ & $0.221(0.009)$ & $93.8(1.7)$ \\
\hline & $60 \mathrm{ppb} \mathrm{O}_{3}$ & $0.633(0.056)$ & $84.8(0.5)$ & $0.226(0.018)$ & $96.8(1.8)$ \\
\hline & $100 \mathrm{ppb} \mathrm{\textrm {O } _ { 3 }}$ & $0.649(0.024)$ & $85.8(0.6)$ & $0.232(0.013)$ & $97.3(1.2)$ \\
\hline \multirow{3}{*}{$\begin{array}{l}\text { Kinuhikari } \\
\text { (9th leaf) }\end{array}$} & $\mathrm{CF}$ & $0.479(0.012)$ & $75.9(1.0)$ & $0.192(0.016)$ & $95.8(1.4)$ \\
\hline & $60 \mathrm{ppb} \mathrm{O}_{3}$ & $0.618(0.048)$ & $82.0(4.2)$ & $0.214(0.019)$ & $97.0(1.1)$ \\
\hline & $100 \mathrm{ppb} \mathrm{\textrm {O } _ { 3 }}$ & $0.653(0.019)$ & $84.7(0.5)$ & $0.201(0.023)$ & $95.3(1.7)$ \\
\hline \multirow[t]{3}{*}{ ANOVA } & $\mathrm{O}_{3}$ & $* *$ & $*$ & n.s. & n.s. \\
\hline & Cultivar & n.s. & $*$ & n.s. & n.s. \\
\hline & $\mathrm{O}_{3} \times$ Cultivar & n.s. & n.s. & n.s. & n.s. \\
\hline \multirow{3}{*}{$\begin{array}{l}\text { Koshihikari } \\
\text { (12th leaf) }\end{array}$} & $\mathrm{CF}$ & $0.753(0.118)$ & $81.8(3.4)$ & $0.244(0.017)$ & $92.5(3.0)$ \\
\hline & $60 \mathrm{ppb} \mathrm{O}_{3}$ & $0.732(0.079)$ & $78.8(6.8)$ & $0.232(0.020)$ & $89.3(2.9)$ \\
\hline & $100 \mathrm{ppb} \mathrm{\textrm {O } _ { 3 }}$ & $0.834(0.041)$ & $84.9(2.0)$ & $0.250(0.022)$ & $93.3(1.0)$ \\
\hline \multirow{3}{*}{$\begin{array}{l}\text { Kinuhikari } \\
\text { (11th leaf) }\end{array}$} & $\mathrm{CF}$ & $0.716(0.025)$ & $81.6(2.7)$ & $0.228(0.044)$ & $92.3(3.6)$ \\
\hline & $60 \mathrm{ppb} \mathrm{\textrm {O } _ { 3 }}$ & $0.718(0.062)$ & $83.0(2.4)$ & $0.237(0.046)$ & $96.9(2.2)$ \\
\hline & $100 \mathrm{ppb} \mathrm{\textrm {O } _ { 3 }}$ & $0.786(0.071)$ & $83.4(2.4)$ & $0.243(0.092)$ & $96.3(1.1)$ \\
\hline \multirow[t]{3}{*}{ ANOVA } & $\mathrm{O}_{3}$ & n.s. & n.s. & n.s. & n.s. \\
\hline & Cultivar & $*$ & n.s. & n.s. & n.s. \\
\hline & $\mathrm{O}_{3} \times$ Cultivar & n.s. & n.s. & n.s. & n.s. \\
\hline \multirow{3}{*}{$\begin{array}{l}\text { Koshihikari } \\
\text { (Flag leaf) }\end{array}$} & $\mathrm{CF}$ & $0.716(0.038)$ & $85.5(0.9)$ & $0.171(0.008)$ & $89.6(4.1)$ \\
\hline & $60 \mathrm{ppb} \mathrm{\textrm {O } _ { 3 }}$ & $0.715(0.052)$ & $83.8(4.2)$ & $0.175(0.013)$ & $84.2(7.9)$ \\
\hline & $100 \mathrm{ppb} \mathrm{\textrm {O } _ { 3 }}$ & $0.677(0.045)$ & $80.8(1.5)$ & $0.169(0.025)$ & $91.4(8.8)$ \\
\hline \multirow{3}{*}{$\begin{array}{l}\text { Kinuhikari } \\
\text { (Flag leaf) }\end{array}$} & $\mathrm{CF}$ & $0.711(0.044)$ & $84.3(0.8)$ & $0.188(0.020)$ & 93.3 (4.9) \\
\hline & $60 \mathrm{ppb} \mathrm{\textrm {O } _ { 3 }}$ & $0.660(0.125)$ & $84.8(5.5)$ & $0.196(0.011)$ & $94.0(1.9)$ \\
\hline & $100 \mathrm{ppb} \mathrm{\textrm {O } _ { 3 }}$ & $0.750(0.070)$ & $84.9(5.0)$ & $0.216(0.017)$ & 89.4 (7.3) \\
\hline \multirow[t]{3}{*}{ ANOVA } & $\mathrm{O}_{3}$ & n.s. & n.s. & n.s. & n.s. \\
\hline & Cultivar & n.s. & n.s. & $*$ & n.s. \\
\hline & $\mathrm{O}_{3} \times$ Cultivar & n.s. & n.s. & n.s. & n.s. \\
\hline
\end{tabular}

The plants were exposed daily to charcoal-filtered air (CF) or $\mathrm{O}_{3}$ at $60 \mathrm{ppb}$ or $100 \mathrm{ppb}$ (10:00-17:00) from 30 May to 21 August 2007. Each value is the mean of 3 chamber replicates, and the standard deviation is shown in parentheses.

Two-way ANOVA: ${ }^{*} P<0.05, * * P<0.01$, n.s. $=$ not significant

When a significant combined effect of $\mathrm{O}_{3}$ and cultivar was detected, Turkey's HSD test was performed to identify significant differences among the 6 treatments. Values with different letters are significantly different at $P<$ 0.05 . 

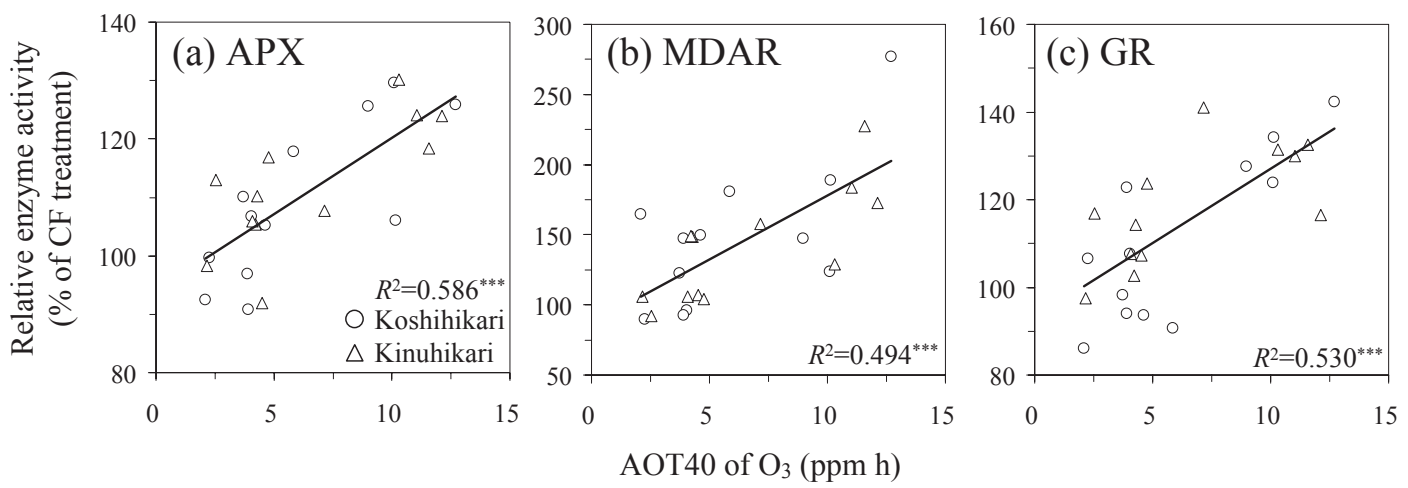

Fig. 1. The relationships between the AOT40 of $\mathrm{O}_{3}$ and the relative activity of APX, MDAR or GR in the leaves exposed to $\mathrm{O}_{3}$ to that in the leaves exposed to charcoal-filtered air of the two rice cultivars. The plots show the data pooled among the leaves within approximately one month from the emergence.

significant differences among the 6 treatments.

\section{Results}

Table 1 shows the effects of $\mathrm{O}_{3}$ on the concentration of chlorophyll $(a+b)$ and the activity and concentration of Rubisco in the leaves of the two rice cultivars. The concentration of chlorophyll in the 8th and 10th leaves of Koshihikari and the 7th and 9th leaves of Kinuhikari was significantly reduced by the exposure to $\mathrm{O}_{3}$. However, the concentration of chlorophyll in the flag leaf of both cultivars was not significantly affected by the exposure to $\mathrm{O}_{3}$, while the activity of Rubisco in the 8th and 10th leaves of Koshihikari and the 7th and 9th leaves of Kinuhikari was not significantly affected by exposure to $\mathrm{O}_{3}$. In contrast, the activity of Rubisco in the flag leaf of both cultivars was significantly increased by the exposure to $\mathrm{O}_{3}$, although the latter did not significantly affect the concentration of Rubisco in the leaves of both cultivars. There was no significant combined effect of $\mathrm{O}_{3}$ and cultivar on the concentration of chlorophyll and activity and the concentration of Rubisco in the leaves of both cultivars.

Table 2 indicates the effects of $\mathrm{O}_{3}$ on the activities of radical scavenging enzymes in the leaves of the two rice cultivars. The activity of SOD was not significantly affected by the exposure to $\mathrm{O}_{3}$, although the activity of CAT was significantly reduced in the 8th leaf of Koshihikari and the 7th leaf of Kinuhikari, and significantly increased in the 12th and flag leaves of Koshihikari and the 11th and flag leaves of Kinuhikari by the exposure to $\mathrm{O}_{3}$. The exposure to $\mathrm{O}_{3}$ significantly increased the activities of APX, MDAR and GR in the leaves of both cultivars. The activity of DHAR in the 8th, 10th and 12th leaves of Koshihikari and the 7th, 9th and 11th leaves of Kinuhikari respectively was significantly reduced by the exposure to $\mathrm{O}_{3}$, although there was no significant effect of $\mathrm{O}_{3}$ on the activity of DHAR in the flag leaf of both cultivars, nor any significant combined effect of $\mathrm{O}_{3}$ and cultivar on the activity of radical scavenging enzymes in the leaves of both cultivars.

Table 3 shows the effects of $\mathrm{O}_{3}$ on the concentration and redox state of ascorbate or glutathione in the leaves of the two rice cultivars. The concentration and redox state of ascorbate in the 10th leaf of Koshihikari and the 9th leaf of Kinuhikari were significantly increased by the exposure to $\mathrm{O}_{3}$. In contrast, the exposure to $\mathrm{O}_{3}$ did not significantly affect the concentration and redox state of ascorbate in the 8th, 12th and flag leaves of Koshihikari and the 7th, 11th and flag leaves of Kinuhikari. On the other hand, the concentration and redox state of glutathione were not significantly affected by the exposure to $\mathrm{O}_{3}$. There is no significant combined effect of $\mathrm{O}_{3}$ and cultivar on the concentration of antioxidants in the leaves of both cultivars.

Figure 1 shows the relationships between the AOT40 of $\mathrm{O}_{3}$ from the leaf emergence to the measurement day of enzyme activity (within approximately 30 days) and the relative activity of APX, MDAR or GR in the leaves exposed to $\mathrm{O}_{3}$ to that in leaves exposed to charcoal-filtered air of both cultivars. A positive correlation was obtained between the AOT40 of $\mathrm{O}_{3}$ and relative activity of APX $\left(R^{2}=0.586^{* * *}\right)$, MDAR $\left(R^{2}=0.494^{* * *}\right)$ or GR $\left(R^{2}=0.530^{* * *}\right)$. However, no significant correlations were obtained between the AOT40 of $\mathrm{O}_{3}$ and the relative activity of SOD, CAT 
or DHAR in the leaves exposed to $\mathrm{O}_{3}$ to that in the leaves exposed to charcoal-filtered air of both cultivars (data not shown).

\section{Discussion}

In the present study, no significant differences were observed in the effects of $\mathrm{O}_{3}$ on the concentration of chlorophyll, activity and the concentration of Rubisco, the activities of radical scavenging enzymes and the concentrations of antioxidants between the two cultivars of rice (Tables 1, 2 and 3). However, the effects $\mathrm{Of}_{3}$ on the concentration of chlorophyll, the activity of Rubisco and the activities of radical scavenging enzymes differed significantly among the leaf positions (Tables 1,2 and 3). According to previous studies, the concentration of chlorophyll in mature leaves of several crops was reduced by exposure to $\mathrm{O}_{3}$ (Nie et al. 1993; Chernikova et al. 2000). The results obtained in the present study indicate that the effects of $\mathrm{O}_{3}$ on the concentration of chlorophyll in the leaves of Japanese rice differ among the leaf positions, even if the period of exposure to $\mathrm{O}_{3}$ is the same among the leaves. Therefore, the detoxification capacity of rice leaf to ROS induced by exposure to $\mathrm{O}_{3}$ may differ among the leaf positions.

The sensitivity of crops to $\mathrm{O}_{3}$ is influenced by the detoxification capacity of ROS in the leaves (Nouchi 1993; Bender et al. 1994; Chernikova et al. 2000; Cheng et al. 2007). In the present study, the activities of radical scavenging enzymes such as APX, MDAR and GR in the leaves of both cultivars of rice were significantly increased by the exposure to $\mathrm{O}_{3}$ (Table 2). It was reported that the activities of APX and GR were also increased by exposure to $\mathrm{O}_{3}$ in rice (Nouchi 1993) in addition to the other environmental stresses such as UV-B radiation (Kim et al. 1996). Furthermore, the $\mathrm{O}_{3}$-induced reduction of DHAR activity and the increase of MDAR activity in the leaves of both cultivars are in agreement with the results obtained from previous studies with Arabidopsis (Kubo et al. 1995, 1999). According to Kubo et al. (1999), the activities of APX and DHAR show an antagonistic response to $\mathrm{O}_{3}$. When the monodehydroascorbate radical was directly reduced to ascorbate by MDAR, no dehydroascorbate radical was produced (Kubo et al. 1999). In the present study, furthermore, a highly positive correlation was obtained between the AOT40 of $\mathrm{O}_{3}$ and relative activity of APX, MDAR or GR in the leaves exposed to $\mathrm{O}_{3}$ to that in the leaves exposed to charcoal-filtered air of the two rice cultivars (Fig. 1). Therefore, APX, MDAR and GR are considered to play a predominant role in the detoxification of $\mathrm{O}_{3}$ in the leaves of rice.

In the present study, the whole-plant dry mass and grain yield per plant of both cultivars at the final harvest were significantly reduced by the exposure to $\mathrm{O}_{3}$ (data not shown, Yamaguchi et al. 2008). In addition, the relative growth rate of both cultivars during the vegetative period was significantly reduced by the exposure to $\mathrm{O}_{3}$. During the vegetative period, furthermore, the exposure to $\mathrm{O}_{3}$ significantly reduced the net assimilation rate and net photosynthetic rate in the two cultivars. These results suggested that the increase in the activity of radical scavenging enzymes such as APX, MDAR and GR was insufficient to prevent the adverse effects of $\mathrm{O}_{3}$ on the concentration of chlorophyll, photosynthetic capacity, growth and yield of both cultivars. The exposure to $\mathrm{O}_{3}$ significantly reduced the activity of CAT in the lower leaves, such as the 8th leaf of Koshihikari and the 7th leaf of Kinuhikari (Table 2). This result is coincident with that obtained from the previous study with Arabidopsis (Kubo et al. 1995). Since $\mathrm{H}_{2} \mathrm{O}_{2}$ and $\mathrm{O}_{2}{ }^{-}$inactivate radical scavenging enzymes such as CAT (Bray et al. 1974; Kono and Fridovich 1982; Kirkman et al. 1987), the $\mathrm{O}_{3}$-induced accumulation of ROS in the leaves of both cultivars at the early stage of the growth period might lead to a reduction in the activity of CAT.

There were no significant effects of $\mathrm{O}_{3}$ on the concentrations of Rubisco and chlorophyll, but the activity of Rubisco in the flag leaves of both cultivars of rice was significantly increased by the exposure to $\mathrm{O}_{3}$ (Table 1). This may be due to the high detoxification capacity to ROS caused by the increase in the activities of CAT, APX, MDAR and GR in the flag leaf (Table 2). The flag leaf may need to acquire high physiological activity in order to provide carbohydrates for developing ear (Wardlaw 1968). Therefore, the results obtained from the present study indicated that the flag leaves of rice possess high levels of detoxification capacity to ROS as compared with the lower leaves. In the present study, the concentration and redox state of ascorbate in the 10th leaf of Koshihikari and the 9th leaf of Kinuhikari were significantly increased by the exposure to $\mathrm{O}_{3}$ (Table 3). Ascorbate also plays an important role in the detoxification of $\mathrm{O}_{3}$ (Conkin et al. 1996; Cheng et al. 2007). Therefore, the $\mathrm{O}_{3}$-induced increase in the concentration of ascorbate in the leaves of both 
cultivars might prevent the $\mathrm{O}_{3}$-induced reduction in the activity of CAT. Furthermore, the $\mathrm{O}_{3}$-induced reduction in the concentration of chlorophyll in the 8th leaf of Koshihikari and the 7th leaf of Kinuhikari might be related to the $\mathrm{O}_{3}$-induced reduction in the activity of CAT in the leaves. In the present study, the difference in the timing of leaf emergence during the growth period changes the extent of the effects of $\mathrm{O}_{3}$ on the concentration of chlorophyll, even if the period of exposure to $\mathrm{O}_{3}$ was the same in the leaves. Therefore, the difference in the effects of $\mathrm{O}_{3}$ on the concentration of chlorophyll among the leaf positions is considered to be mainly attributable to that in the detoxification capacity to ROS induced by the exposure to $\mathrm{O}_{3}$.

In conclusion, APX, MDAR and GR are considered to play important roles in the antioxidative response of Japanese rice to $\mathrm{O}_{3}$. However, the detoxification capacity of reactive oxygen species by APX, MDAR and GR is insufficient to prevent the adverse effects of ambient levels of $\mathrm{O}_{3}$ on the concentration of chlorophyll in the leaves of Japanese rice.

\section{Acknowledgments}

This study was financially supported by the Ministry of the Environment, Japan through the program of the Global Environment Research Fund (C-062). The authors are greatly indebted to Dr. Haruto Sasaki (The University of Tokyo) for his invaluable advice, as well as to Prof. Hiroshi Hara (Tokyo University of Agriculture and Technology) for his smooth work execution. The authors also acknowledge Mr. Masayoshi Uchida (Tokyo University of Agriculture and Technology) for his technical support.

\section{Reference}

Aebi, H., 1984: Catalase in vitro. Method. Enzymol., 105, 121-126.

Barnes, J. D., Balaguer, L., Manrique, E., Elvira, S., and Davison, A. W., 1992: A reappraisal of the use of DMSO for the extraction and determination of chlorophylls $a$ and $b$ in lichens and higher plants. Environ. Exp. Bot., 32, 85-100.

Bender, J., Weigel, H. J., Wegner, U., and Jäger, H. J., 1994: Response of cellular antioxidants to ozone in wheat flag leaves at different stages of plant development. Environ. Pollut., 84, 15-21.

Bradford, M. M., 1976: A rapid and sensitive method for the quantitation of microgram quantities of protein utilizing the principle of protein-dye binding.
Anal. Biochem., 72, 248-254.

Bray, R. C., Cockle, S.A., Fielden, E. M., Roberts, P. B., Rotilio, G., and Calabrese, L., 1974: Reduction and inactivation of superoxide dismutase by hydrogen peroxide. Biochem. J., 139, 43-48.

Chameides, W. L., Kashibhatla, P.S., Yienger, J. and Levy, H., 1994: Growth of continental-scale metroagro-plexes, regional ozone pollution, and world food production. Science, 64, 74-77.

Cheng, F. Y., Burkey, K. O., Robinson, J. M., and Booker, F. L., 2007: Leaf extracellular ascorbate in relation to $\mathrm{O}_{3}$ tolerance of two soybean cultivars. Environ. Pollut., 150, 355-362.

Chernikova, T., Robinson, J. M., Lee, E. H., and Mulchi, C. L., 2000: Ozone tolerance and antioxidant enzyme activity in soybean cultivars. Photosyn. Res., 64, 15-26.

Collins, W. J., Stevenson, D. S., Johnson, C. E., and Derwent, R. G., 2000: The European regional ozone distribution and its links with the global scale for the years 1992 and 2015. Atmos. Environ., 34, 255-267.

Conklin, P. L., Williams, E. H., and Last, R. L., 1996: Environmental stress sensitivity of an ascorbic aciddeficient Arabidopsis mutant. Proc. Natl. Acad. Sci. USA, 93, 9970-9974.

Dann, M. S., and Pell, E. J., 1989: Decline of activity and quantity of ribulose bisphosphute carboxylase/ oxygenase and net photosynthesis in ozone-treated potato foliage. Plant Physiol., 91, 427-432.

Farage, P. K., Long, S. P., Lechner, E. G., and Baker, N. R., 1991: The sequence of change within the photosynthetic apparatus of wheat following short-term exposure to ozone. Plant Physiol., 95, 529-535.

Foyer, C. H., and Halliwell, B., 1976: The presence of glutathione and glutathione reductase in chloroplasts: A proposed role in ascorbic acid metabolism. Planta, 133, 21-25.

Fuhrer, J., Skärby, L., and Ashmore, M. R., 1997: Critical levels for ozone effects on vegetation in Europe. Environ. Pollut., 97, 91-106.

Fuhrer, J., and Booker, F., 2003: Ecological issues related to ozone: agricultural issues. Environ. Intern., 29, 141-154.

Griffith, O. W., 1980: Determination of glutathione and glutathione disulfide using glutathione reductase and 2-vinylpyridine. Anal. Biochem., 106, 207-212.

Heck, W. W., Taylor, O. C., Adams, R., Bingham, G., Miller, J., Preston, E., and Weinstein, L. H., 1982: 
Assessment of crop loss from ozone. J. Air Pollut. Control Assoc., 32, 353-361.

Hippeli, S., and Elstner, E. F., 1996: Mechanisms of oxygen activation during plant stress: biochemical effects of air pollutants. J. Plant Physiol., 148, 249-257.

Hoigné, J., and Bader, H., 1976: The role of hydroxyl radical reactions in ozonation processes in aqueous solutions. Water Res., 10, 377-386.

Hossain, M. A., and Asada, K., 1984: Purification of dehydroascorbate reductase from spinach and its characterization as a thiol enzyme. Plant Cell Physiol., 25, 85-92.

Hossain, M. A., Nakano, Y., and Asada, K., 1984: Monodehydroascorbate reductase in spinach chloroplasts and its participation in regeneration of ascorbate for scavenging hydrogen peroxide. Plant Cell Physiol., 25, 385-395.

Izuta, T., Takahashi, K., Matsumura, H., and Totsuka, T., 1999: Cultivar difference of Brassica campestris L. in the sensitivity to $\mathrm{O}_{3}$ based on the dry weight growth. J. Jpn. Soc. Atmos. Environ., 34, 137-146.

Kim, H. Y., Kobayashi, K., Nouchi, I., and Yoneyama, T., 1996: Differential influences of UV-B radiation on antioxidants and related enzymes between rice (Oryza sativa L.) and cucumber (Cucumis sativus L.) leaves. Environ. Sci., 9, 55-63.

Kirkman, H. N., Galiano, S., and Gaetani, G.F., 1987: The function of catalase-bound NADPH. J. Biol. Chem., 262, 660-666.

Kobayashi, K., 1988: Effects of atmospheric ozone on the production of soybean and peanut in Kanto district of Japan. Environ. Pollut., 53, 437-438.

Kono, Y., and Fridovich, I., 1982: Superoxide radical inhibits catalase. J. Biol. Chem., 257, 5751-5754.

Kubo, A., Saji, H., Tanaka, K., and Kondo, N., 1995: Expression of arabidopsis cytosolic ascorbate peroxidase gene in response to ozone or sulfur dioxide. Plant Molecular Biology, 29, 479-489.

Kubo, A., Aono, M., Nakajima, N., Saji, H., Tanaka, K., and Kondo, N., 1999: Differential responses in acitivity of antioxidant enzymes to different environmental stresses in Arabidopsis thaliana. J. Plant Res., 112, 279-290.

Laemmli, U. K., 1970: Cleavage of structural protein during the assembly of the head of bacteriophage T4. Nature, 227, 680-685.

Luwe, M., and Heber, U., 1995: Ozone detoxification in the apoplasm and symplasm of spinach, broad bean and beech leaves at ambient and elevated concentrations of ozone in air. Planta, 197, 448-455.

McCord, J. M., and Fridovich, I., 1969: Superoxide dismutase. J. Biol. Chem., 244, 6049-6055.

Nakano, Y., and Asada, K., 1981: Hydrogen peroxide is scavenged by ascorbate-specific peroxidase in spinach chloroplasts. Plant Cell Physiol., 22, 867-880.

Nie, G. Y., Tomasevic, M., and Baker, N. R., 1993: Effects of ozone on the photosynthetic apparatus and leaf proteins during leaf development in wheat. Plant, Cell Environ., 16, 643-651.

Nouchi, I., 1993: Changes in antioxidant levels and activities of related enzymes in rice leaves exposed to ozone. Soil Sci. Plant Nutr., 39, 309-320.

Nouchi, I., Ito, O., Harazono, Y., and Kobayashi, K., 1991: Effects of chronic ozone exposure on growth, root respiration and nutrient uptake of rice plants. Environ. Pollut., 74, 149-164.

Ohara, T., Akimoto, H., Kurokawa, J., Horii, N., Yamaji, K., Yan, X., and Hayasaka, T., 2007: An Asian emission inventory of anthropogenic emission sources for the period 1980-2020. Atmos. Chem. Phys. 7, 4419-4444.

Tissue, D. T., Thomas, R. B., and Strain, B. R., 1993: Long-term effects of elevated $\mathrm{CO}_{2}$ and nutrients on photosynthesis and rubisco in loblolly pine seedlings. Plant Cell Environ., 16, 859-865.

Wardlaw, I. F., 1968: The control and pattern of movement of carbohydrates in plants. Bot. Rev., 34, 79-105.

Yamaguchi, M., Inada, H., Satoh, R., Hoshino, D., Nagasawa, A., Negishi, Y., Sasaki, H., Nouchi, I., Kobayashi, K., and Izuta, T., 2008: Effects of ozone on the growth, yield and leaf gas exchange rates of two Japanese cultivars of rice (Oryza sativa L.). J. Agric. Meteorol., 64, 131-141.

Yoshida, M., Nouchi, I., and Toyama, S., 1994a: Studies on the role of active oxygen in ozone injury to plant cells. I. Generation of active oxygen in rice protoplasts exposed to ozone. Plant Science, 95, 197-205.

Yoshida, M., Nouchi, I., and Toyama, S., 1994b: Studies on the role of active oxygen in ozone injury to plant cells. II. Effect of antioxidants on rice protoplasts exposed to ozone. Plant Science, 95, 207-212.

Zheng, Y., and Shimizu, H., 2003: Air Pollution impacts on crops and forests, Imperial College Press, London, pp. 123-144. 


\title{
イネの葉の光合成関連要素と活性酸素消去系に対する オゾンの影響
}

\author{
稲田秀俊 $*$ - 山口真弘 $*$ ・佐藤亮平 $*$. 星野大起 $*$ ・長澤亜季 $*$. \\ 根岸 蓉 $*$ ・野内 勇 $* *$ ・小林和彦 $* *$ ・伊豆田 猛* \\ $\left(\begin{array}{c}* \text { 東京農工大学大学院 共生科学技術研究院 } \\ * * \text { 東京大学大学院 農学生命科学研究科 }\end{array}\right)$
}

要約

イネの葉における RubP カルボキシラーゼ / オキシゲ ナーゼ (Rubisco) の活性・濃度, クロロフィル濃度, 活性酸素消去系に対するオゾン $\left(\mathrm{O}_{3}\right)$ の影響を調べた。 2007 年 5 月 15 日に黒ボク土を詰めたコンテナにコシヒ カリとキヌヒカリの幼苗を移植し, チャンバー内で 5 月 30 日から 9 月 20 日までガス処理を行った。ガス処理区とし て, 活性炭フィルターによって浄化した空気をチャンバー 内に導入した浄化空気区，毎日 10:00 から 17:00 まで チャンバー内の $\mathrm{O}_{3}$ 濃度を $60 \mathrm{nl} \mathrm{l}^{-1}(\mathrm{ppb})$ に制御した 60 $\mathrm{ppb} \mathrm{O}_{3}$ 区および同時刻の $\mathrm{O}_{3}$ 濃度を $100 \mathrm{ppb}$ に制御し た 100 ppb O3 区を設けた。O 3 暴露によって, Rubisco の活性・濃度に有意な影響は認められなかったが，葉の クロロフィル濃度は有意に低下した。 $\mathrm{O} 3$ 暴露によって両 品種のアスコルビン酸ペルオキシダーゼ (APX), モノデ
ヒドロアスコルビン酸レダクターゼ (MDAR) およびグル タチオンリダクターゼ $(\mathrm{GR})$ の活性が有意に増加し, 浄 化空気区に対する $\mathrm{O}_{3}$ 暴露区における酵素活性の増加程 度と O3 の AOT40 との間に有意な正の相関が認められ た。以上の結果より, 野外濃度レベルの O3 を長期間に わたって暴露されたイネの葉では APX, MDAR および GR が抗酸化応答において重要な役割を果たすと考えら れたが, これらの酵素の活性上昇は O3 によるクロロフィ 儿濃度の低下を回避するには不十分であることが明らか になった。

キーワード：イネ, オゾン, 活性酸素消去系酵素, 抗 酸化物質, RubPカルボキシラーゼ/オキ シゲナーゼ (Rubisco) 